\title{
Sustainability of processed foods supply chain: Social, economic and territorial performance
}

\author{
Caetano Beber ${ }^{1}$, Martine Padilla ${ }^{1}$, Maylis Razès ${ }^{1}$, Fatiha Fort ${ }^{2}$, and Jean-Louis Rastoin ${ }^{2}$ \\ ${ }^{1}$ CIHEAM-IAMM, 3191 route de Mende, 34090 Montpellier, France \\ ${ }^{2}$ Montpellier SupAgro, UMR 1110 MOISA, Place Viala, 34000 Montpellier, France
}

\begin{abstract}
In a global market, food companies engaged in sustainable development must now integrate the economic and social component. However the tools to assess it are lacking. Several theoretical frameworks have been developed to define social sustainability and its implementation. The attributional approaches, pathways or capabilities methods have emerged, based on a functional unit of a good or service along the supply chain. This paper proposes a new method to assess social economic and territorial performances of a food chain as a whole on a Territory. It is divided into four components: (i) dignity and well-being of workers, (ii) contribution to local life, (iii) fairness and integrity of business practices, and (iv) creation of material and intangible wealth. 50 criteria are used according to international, national or sectoral references. This generic method applicable to any sector of processed food products aims to identify where are the areas of improvement to qualify the sector as socially sustainable. An application to the wine Beaujolais and Burgundy wine was performed from surveys of 35 production and trade operators in 2014. The results show that the sector is particularly effective for the promotion of the territory, local life participation, loyalty and integrity of business practices; some improvement is still possible for the welfare of workers and the creation of material wealth. This method can be coupled with the environmental performance determined by the life cycle analysis in order to assess the sustainability in its entirety.
\end{abstract}

\section{Introduction}

In the saturated food products market of nowadays, the competition between companies and sectors is first done by the economic performance shortly followed by the performance in terms of sustainability. The environmental component is now admitted as essential; for economic and social aspects, conceptualization and implementation are under discussion. Creating value and innovation, the social responsibility is now a real competitiveness challenge and a major strategic lever to meet the expectations of stakeholders.

During the last decade, efforts have been done to develop theoretical frameworks to define and study social sustainability and empirical research in terms of "sustainable development projects", "practice of sustainability" and "sustainable development initiatives" [1]. It brings out the social and societal (linked to the society) issues, which are increasingly taken into account in organizations. Measuring the social impact is becoming every time more important in the sphere of sustainable development. The Supreme Council of the Social and Solidarity Economy defines "social impact as all the consequences of activities of an organization both over its external stakeholders directly or indirectly from its territory and internal (employees, volunteers), and over society in general. Thus the term refers to the implementation of Corporate Social Responsibility (CSR). Social performance aims to promote the relationship between the result achieved and the means used to achieve it.
Aware of it, investors worried about the risk of impairment related to its negative impacts beyond the actions of extra-financial rating agencies and NGOs, and especially the legislative constraint, have certainly encouraged companies to produce indicators more sophisticated to improve information and transparency on their activities and externalities. The establishment of social performance indicators alongside environmental performance indicators represents that concern. Among the methodologies for measuring impacts, Life Cycle Assessment - LCA (regulated by the series ISO 14040) is the dominant approach for the evaluation of supply chains and adopted as the basis for eco-design policy and redesign of industrial products in Europe.

However, the Social LCA (SLCA) is still striving to attain its maturity [2]. It is at an early stage of development where general consensus still has a long way. The multitude of approaches developed show that the perception of social impacts is very variable. This might be caused by confusion on the goal and scope of SLCA and a lack of data and practical tools to experience the full breadth of what SLCA seeks to offer [3] (Norris, 2014). However, an agreement regarding the impacts that are most relevant to include in the SLCA to cover the social field seems essential if the SLCA intends to gain importance as a tool for decision making and not to be only a reporting or marketing tool ("social-washing") or just proof of proper allocation of funds but also to promote improvements.

Up to this point, the method does not allow accessing the real impacts of activities and presents many challenges 
to adapt to the quantification and assessment the behaviors of such a variety of operators. Because today between too much or not enough criteria, between the quantitative or qualitative data, methodologies vary and there is no consensus on which is the most complete and the most relevant. Also arise issues of cost, good time to set them up (before, during, after), the external solution (more objective) or internal (more aware of the land), or shared among several organisms.

The existing methods SLCA refer to three schools. One measures social performance (mid-point attributes) that are integrated into the field of CSR [4-7]. The second measures the impacts (end-point, pathway), which seeks to assess the real social impacts and to establish causal and functional relationships [8-12]. The third being intermediate and focus on the effects (the capabilities of Amartya Sen) that is based on the Multiple Capital Model and seeks to measure the impact of corporate action on the transformation of individual endowments on additional operating capacity of actors [13]. The implementation of these concepts into operational methods is difficult; one of the main difficulties is to select the most explicit indicators from among the existing hundreds. The ANIA (National Association of Agrofood industries) in France tried to achieve this goal through the development of a user's guide of ISO 26000 to the Agrifood industry. It created a practical tool containing all fields of CSR into 31 themes on a scale of 5 levels scores; applied to an enterprise they allow to measure the social and economic performance. Thus all existing methods concern either an enterprise or a functional unit of a good or service along a chain of production-distribution-consumption. None can measure the economic and social performance of a given sector as a whole in a given territory [14].

This paper proposes a new bottom-up method to assess the social, economic and territorial performances of a supply chain on a Territory. It was developed in three French supply chains under indication of origin (wines of Burgundy and Beaujolais, Comté cheese and Southwest foie gras) as part of the ANR-ALID ACYDU ${ }^{1}$ project. This method aims to provide companies and supply chains an operational tool that can be combined with environmental life cycle analysis, to describe their social practices, measure their socio-economic performance in a context of strong pressure on responsibility of the productive sectors vis-à-vis of society.

In this paper, we apply the methodology to Beaujolais and Burgundy wines sector in France. This includes particular features (location of operators in the appellation area and connection to territory; reasoning at the supply chain scale) that will be addressed over the steps detailed below. We do not aim to anticipate the consequences of a choice neither to classify alternatives. Our performance and effects evaluation should be taken in the sense that we seek to measure the contribution of a supply chain under geographical indication to the social, economic and territorial development.

\footnotetext{
${ }^{1}$ The ACYDU project (2013-2016) on socio-economic, territorial and environmental sustainability of processed food is a partnership between the CTCPA, BIVB, CIHEAM-IAMM, ENIL Mamirolle, IFV, ITERG, Montpellier SupAgro, UMR Théma (CNRS, Franche-Comté University) and UNGDA. It's funded by the French National Research Agency.
}

\section{Methodology for measuring performances}

The limitations of current methodologies and data available have led us to develop a hybrid method rather than stand behind an existing conceptual school. The following concerns have marked our thoughts:

- The decision of measure the practices and performances instead of impacts since impact models are under too much confounders;

- The desire to have references to judge/positioning the performance and the indicators measured;

- Our goal is not to verify the compliance with regulations or specifications but to identify areas for improvement

- The willingness of a sufficiently generic method to adapt to other sectors.

\subsection{Performance scores}

The SLCA methods described in the literature are called "social" but they include actually economy indicators as well. The boundaries between the social, economic and territorial considerations are blurred. So we have decided to organize the three areas of interest without partitioning social, economic and territorial aspects.

In practice, the different disciplines are combined and organized into four major categories of variables: Dignity and Welfare of Workers, Loyalty and Integrity of Commercial Practices, Territory Promotion and Integration in Local Life and Wealth Creation. The table 1 summarizes the proposed subcategories for each category. These sub-categories are further divided into 50 indicators.

For each subcategory, a series of indicators has been developed to assign a performance score that will characterize the operator according to the references adopted i.e. the references are the basis for the definition of performance scales. International references should be preferred, then national, followed by the ones of the sector or the Geographical Indication chain, and finally a collective agreement. The difficulty here falls on the existence of such references or studies to serve as a base.

Indicators scores ranges between 0 and 10 points, where 10 represents the best performance. The number of indicators varies between subcategories and categories, which assigns more importance to some than others. In short we made an indirect weighting. E.g.: The category "Dignity and welfare of workers (190 points)" has more importance on the overall impact that the category "Territory Promotion and integration in local life" (50 points). The categories are divided as shown in Fig. 1.

Not all companies are affected by all sub-categories. Indeed, some of them do not employ such statutes "precarious employees" (trainees, apprentices etc.) and / or does not involve subcontracting. In this case a weighting is made only with the involved companies.

\subsection{Choice of scales and scores associated}

For each indicator we have established a score scale. Several scales have been built on empirical data and research. The strength of this notation is to be able to compare the results of three very different sectors to build the scales. So we set up a scheme incorporating a wide 
Table 1. Performance Assessment Grid.

\begin{tabular}{|c|c|c|c|c|c|}
\hline $\begin{array}{l}\text { CATEGORY OF } \\
\text { PERFORMANCE }\end{array}$ & SUB-CATEGORIES & INDICATORS & SCORE & \begin{tabular}{|l|} 
SCORE \\
MAX/SUB- \\
CATEGORY
\end{tabular} & \begin{tabular}{|l|} 
SCORE \\
MAX/ \\
CATEGORY
\end{tabular} \\
\hline \multirow{21}{*}{$\begin{array}{c}\text { Dignity and welfare of } \\
\text { workers }\end{array}$} & \multirow[t]{3}{*}{ Health and Safety } & $\begin{array}{l}\text { Severity rate of accidents } \\
\text { and occupational } \\
\text { diseases }\end{array}$ & $0-5-10$ & \multirow{3}{*}{130} & \multirow{21}{*}{$/ 185$} \\
\hline & & $\begin{array}{l}\text { Difficult working } \\
\text { conditions }\end{array}$ & $0-7-10$ & & \\
\hline & & $\begin{array}{l}\text { Safety and security of } \\
\text { wokers }\end{array}$ & $0-7-10$ & & \\
\hline & \multirow{3}{*}{ Work environment } & $\begin{array}{l}\text { Organization of special } \\
\text { events and facilities }\end{array}$ & $0-5-10$ & \multirow{3}{*}{$/ 25$} & \\
\hline & & \begin{tabular}{|l|} 
Organization of working \\
time
\end{tabular} & $0-5-10$ & & \\
\hline & & $\begin{array}{l}\text { Availability of a social } \\
\text { local }\end{array}$ & $0-5$ & & \\
\hline & \multirow{5}{*}{ Benefits for workers } & Benefits in kind & $0-5$ & \multirow{5}{*}{130} & \\
\hline & & $\begin{array}{l}\text { Cultural and material } \\
\text { benefits }\end{array}$ & $0-5$ & & \\
\hline & & $\begin{array}{l}\text { Complementary } \\
\text { retirement pension }\end{array}$ & $0-2-5$ & & \\
\hline & & $\begin{array}{l}\text { Complementary health } \\
\text { insurance }\end{array}$ & $0-2-5$ & & \\
\hline & & Economic advantages & $0-5-10$ & & \\
\hline & \begin{tabular}{|l|} 
Employee \\
Representation
\end{tabular} & $\begin{array}{l}\text { Place for discussion } \\
\text { managers/employees }\end{array}$ & $0-5-10$ & $/ 10$ & \\
\hline & \multirow{4}{*}{$\begin{array}{l}\text { Fight against } \\
\text { precarious status }\end{array}$} & $\begin{array}{l}\text { Compliance with work } \\
\text { schedules and rest }\end{array}$ & $0-10$ & \multirow{4}{*}{140} & \\
\hline & & $\begin{array}{l}\text { Facilities made available } \\
\text { for seasonal workers }\end{array}$ & $0-10$ & & \\
\hline & & $\begin{array}{l}\text { Continuity for seasonal } \\
\text { workers }\end{array}$ & $0-5-10$ & & \\
\hline & & $\begin{array}{l}\text { Limiting seasonal work- } \\
\text { ers from third countries }\end{array}$ & $0-10$ & & \\
\hline & \multirow{5}{*}{ Jobs Characteristics } & Qualification & $0-10$ & \multirow{5}{*}{$/ 50$} & \\
\hline & & \begin{tabular}{|l|} 
Workers'remuneration \\
\end{tabular} & $0-5-10$ & & \\
\hline & & Executive remuneration & $0-5-10$ & & \\
\hline & & $\begin{array}{l}\text { Equity man-woman } \\
\text { among executives }\end{array}$ & $0-5-10$ & & \\
\hline & & Women representation & $0-10$ & & \\
\hline \multirow{6}{*}{ Territory and local life } & \multirow[t]{2}{*}{ Integration in local life } & $\begin{array}{l}\text { Involvement in local } \\
\text { events }\end{array}$ & $0-5-10$ & \multirow[t]{2}{*}{$/ 20$} & \multirow{6}{*}{$/ 60$} \\
\hline & & Nuisances & $0-2-5-10$ & & \\
\hline & \multirow{4}{*}{ Promotion of territory } & $\begin{array}{l}\text { Promotion of territory } \\
\text { identity }\end{array}$ & $0-10$ & \multirow{4}{*}{$/ 40$} & \\
\hline & & Heritage Preservation & $0-5-7-10$ & & \\
\hline & & Institutional recognition & $0-5-10$ & & \\
\hline & & Image of product & $0-5-7-10$ & & \\
\hline \multirow{7}{*}{$\begin{array}{c}\text { Loyalty, integrity of } \\
\text { business practices }\end{array}$} & \multirow{3}{*}{ Entreprises commitments } & Commitment to CSR & $0-2-6-10$ & \multirow{3}{*}{130} & \multirow{7}{*}{$/ 105$} \\
\hline & & $\begin{array}{l}\text { Safety and quality } \\
\text { commitments }\end{array}$ & $0-2-6-10$ & & \\
\hline & & \begin{tabular}{|l|}
$\begin{array}{l}\text { Environmental } \\
\text { commitments }\end{array}$ \\
\end{tabular} & $0-2-6-10$ & & \\
\hline & \multirow{4}{*}{ Subcontracting } & Reasons & $0-10$ & \multirow{4}{*}{135} & \\
\hline & & \begin{tabular}{|l|} 
Arduousness \\
\end{tabular} & $0-5$ & & \\
\hline & & $\begin{array}{l}\text { Commitment to environ- } \\
\text { ment, social and health }\end{array}$ & $0-10$ & & \\
\hline & & $\begin{array}{l}\text { Respect for working } \\
\text { conditions }\end{array}$ & $0-10$ & & \\
\hline
\end{tabular}


Table 1. Continued.

\begin{tabular}{|c|c|c|c|c|c|}
\hline $\begin{array}{l}\text { CATEGORY OF } \\
\text { PERFORMANCE }\end{array}$ & SUB-CATEGORIES & INDICATORS & SCORE & $\begin{array}{l}\text { SCORE MAX/ } \\
\text { SUB-CATEGORY }\end{array}$ & $\begin{array}{l}\text { SCORE MAX/ } \\
\text { CATEGORY }\end{array}$ \\
\hline & \multirow{4}{*}{$\begin{array}{l}\text { Relationships with } \\
\text { partners }\end{array}$} & $\begin{array}{l}\text { Social and environmental } \\
\text { practices of partners }\end{array}$ & $0-2-10$ & \multirow{4}{*}{$/ 40$} & \\
\hline & & Loyalty to partners & $0-5-10$ & & \\
\hline & & $\begin{array}{l}\text { Organisation of events } \\
\text { with partners }\end{array}$ & $0-5-10$ & & \\
\hline & & $\begin{array}{l}\text { Involvement in a } \\
\text { common project }\end{array}$ & $0-10$ & & \\
\hline \multirow{14}{*}{ Wealth creation } & \multirow{11}{*}{ Material wealth } & Added Value rate & $0-5-10$ & \multirow{11}{*}{$/ 110$} & \multirow{13}{*}{$/ 130$} \\
\hline & & Burden of payroll & $0-5-10$ & & \\
\hline & & Economic efficacity & $0-3-7-10$ & & \\
\hline & & Investment rate & $0-5-10$ & & \\
\hline & & Net income in $\%$ of sales & $0-5-10$ & & \\
\hline & & $\begin{array}{l}\text { Rate of dependence on } \\
\text { aid and subsidies }\end{array}$ & $0-10$ & & \\
\hline & & $\begin{array}{l}\text { Appropriation of net in- } \\
\text { come }\end{array}$ & $0-3-7-10$ & & \\
\hline & & Cash flow & $0-5-10$ & & \\
\hline & & Profitability & $0-3-7-10$ & & \\
\hline & & Debt ratio & $0-3-7-10$ & & \\
\hline & & Financial balance & $0-3-7-10$ & & \\
\hline & \multirow{2}{*}{ Immaterial wealth } & Access rate to training & $0-10$ & \multirow[b]{2}{*}{$/ 20$} & \\
\hline & & $\begin{array}{l}\text { Relationships with Edu- } \\
\text { cation and Research }\end{array}$ & $0-5-10$ & & \\
\hline & & & & TOTAL & 480 \\
\hline
\end{tabular}

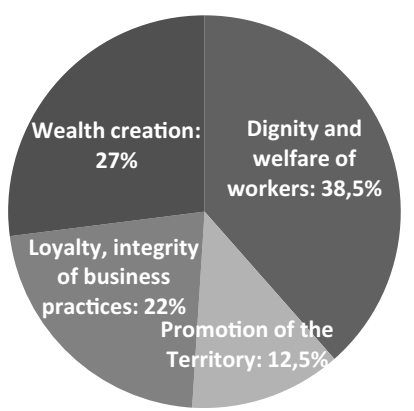

Figure 1. Distribution of performance categories.

variety of cases and quite applicable to the professional world. Indicators and references were discussed with the professionals of the 3 supply chains studied in ACYDU project.

The most common scale is 0 - 5 - 10 where " 0 " is an insufficient level, " 5 " a medium level and "10" an exemplary level. For some indicators we have implemented a four levels scale. Sometimes the difference between each level is disparate, such as for the "CSR Commitment" indicator whose scale is $0-2-6-10$ In this case we judge more difficult for the company to move from the level "awareness about CSR $(=2)$ ", to "the establishment of a formal policy $(=6)$ ". We wanted to highlight this effort by putting a greater differential between level 2 and level 3 than from level 1 to 2 . This will avoid any confusion and doubts in the placement of a company on a score and increases the scientific rigor of the analysis. Thus there would be fewer margins for error or bias of investigator.

The evaluation grid is the fundamental work of the socio-economic LCA. From it we can classify firms according to their individual performance. Ranking scales shall be as detailed as possible to separate the enterprises or regroup them according to their practices. Research and construction of references is made specifically for each supply chain. The availability of references can be more or less difficult depending on the sector. Indeed, although the establishment of the scale on empirical data is quite interesting, it would be necessary to combine them with reference data to increase the quality of the scale and robustness. The reference data may be at larger or smaller scales (country or sector), according to the objective assigned to the indicator.

\subsection{Passage from operator data to the supply chain as a whole}

To pass from the measurements taken at the level of individual operators (enterprise surveys) to the result of the entire supply chain we proceeded in two steps, creating "classes of operators".

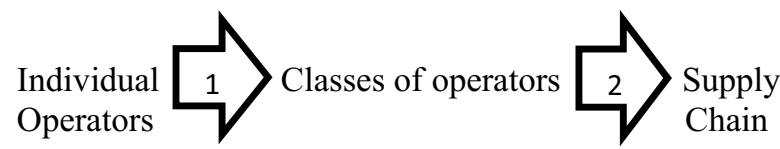

Passage 1:

The score of the individual operator is multiplied by the volume of final product of the operator and brought to the volume of final surveyed operators of the same type. So we obtain a weighted score by type of operator. The weighting can be done on the produced or traded volume, or turnover or FTE. In this article we have made the choice of volume.

Passage 2:

We assigned to each scale score "Operator type" a coefficient that represents the importance of this actor type 
in the supply chain. The coefficient is the part of the volume (or turnover or FTE) represented by our surveyed operators (for 1 same type of operator) to the total volume processed by the Operator type of the sector (data collected with the meta-sector institutions). Finally the final score of the supply chain is the weighted sum of the scores of the different operators type along the supply chain.

\subsection{Economic impacts: Induced income and jobs created in the supply chain}

To measure the economic impact of the supply chain on its territory, we have adopted the "method of multipliers" [15] that consists in applying a multiplier to the initial income generated by the activity. This allows establishing the primary, secondary and tertiary income of this production and thus the wealth and jobs created in the area. This meso-economic approach uses supply multipliers and demand multipliers. These two types of multipliers, which correspond, for the first, on effects of local production of companies, and for the latter the effects of household expenditure, must be articulated to help provide meaningful information on the consequences in terms of total activity created by an independent expenditure. Trivially, an activity generates wages that will be spent in another activity that will generate other wages etc. We also include a multiplier which captures the public expenditures on the territory.

Applying this technique to the economic evaluation of a supply chain, we must consider two injections of different nature: the production / investment (initial injection) and operation (recurring injection) to calculate the primary, secondary and tertiary income:

Primary Income (Direct Added Value / direct local spending): portion of expenditures spent locally with actors of the zone to the purchase of work or intermediate consumption. Primary income $=($ salary + staff costs $)+$ (local intermediary consumption). We do not consider the income related to wine tourism because we are not able to quantify this amount.

Secondary Income (induced): includes household demand that will produce effects and the demand of companies. Secondary income $=$ Income induced from household spending / employees (expenditures related to paid wages: permanent employees in the region, temporary employees, and immigrant employees) + Income induced from local production (Revenue induced by local intermediary expenditures).

Tertiary Income (induced Public spending investment): Primary and secondary income are factors that increase public spending due to the increased use of public services we can assume based on revenue increases. Tertiary income multiplier $=$ Brute Fixed Capital Formation of Public Agencies, which represents in France $=3.0678 \%$ of GDP. The Total Income created in the Area is the sum of primary incomes and induced incomes (secondary and tertiary). Deducting the local subventions received we obtain the Total Net Income Created on The Zone.

To measure the jobs created by the supply chain, we use the ratio $\boldsymbol{a}=$ Jobs / GDP of Burgundy. This ratio must be applied to the total income. It remains that this measure is still very rough because the value of " $a$ " is an average covering all categories of jobs. To measure the total income and jobs created by the supply chain in the territory we used the accounting data of the companies surveyed when they were provided. An estimate was made at the level of the entire chain using total sales of the sector.

\section{Implementation to wines Beaujolais and Burgundy: Main results}

\subsection{Functional unit and boundaries}

The methodology was applied to a product under protected geographical indication: the Beaujolais and Burgundy wines. One feature of the study is its position regarding the supply chain in a whole; so the functional unit used is the amount of wine sold by the supply chain during the wine year 2011-2012.

The appellation area covers 4 administrative departments distributed over two regions. It has various legal forms (sole proprietorship, agricultural family farms, company type SARL / EARL in different sizes, AS, subsidiaries of large cooperative groups etc.). The stakeholders were categorized as follows: the "Main chain operators" (Cooperative winery, Private winery and Traders), the "upstream and downstream stakeholders" (suppliers, service providers / subcontractors), the socalled "nearby environment" including operators which have a supporting role (Management and Defense Organizations, unions, interprofession, technical support and $R \& D$, training and education, public services and local authorities) [16]. The boundaries of our system include the winemaking and the stage of commercialization. This limitation is imposed due to the already excessive extent scope of study. For the induced income and jobs created, we considered the only region Burgundy for reasons of feasibility.

\subsection{Sample constitution and data collection}

To reflect the diversity of organizational forms of the supply chain in the most accurate manner possible and to guide data collection, we have established the various circuits that co-exist in the chain. The overlap between the different structures is complex; indeed traders can market the products of private wineries and all or part of the products of cooperative wineries. A collection plan was formulated to represent the different types and sizes of firms by volume of production. The base year used for the collection is 2011-2012 since this is the last year of representative average crops why companies have the data. A total of 35 operators were interviewed: 4 cooperatives, 8 private wineries, 3 merchants among the Main chain operators; they account for $6 \%$ of the sector's turnover. 1 nursery, 1 distillery, 1 oil factory and 3 providers of products or services among the upstream and downstream stakeholders; 14 institutions from the nearby environment: MSA (Social Agriculture Workers Protection), CER France (Associative Network of Accountant Expertise and Consulting), CA (Agriculture Bureau), federations, syndicates, Inter-professions, consulting and training institutes, tourist offices, etc..

The inventory data relates to economic, social and territorial issues. Primary data were collected by a questionnaire and existing documents in the enterprises. Secondary data (general statistics, studies, etc.) were collected from "Nearby environment operators". 


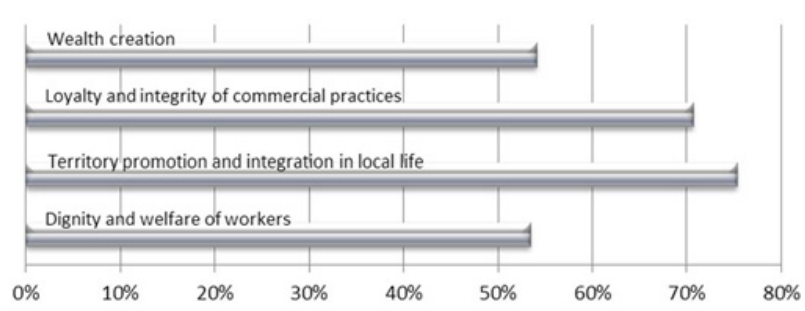

Figure 2. Performance of categories.

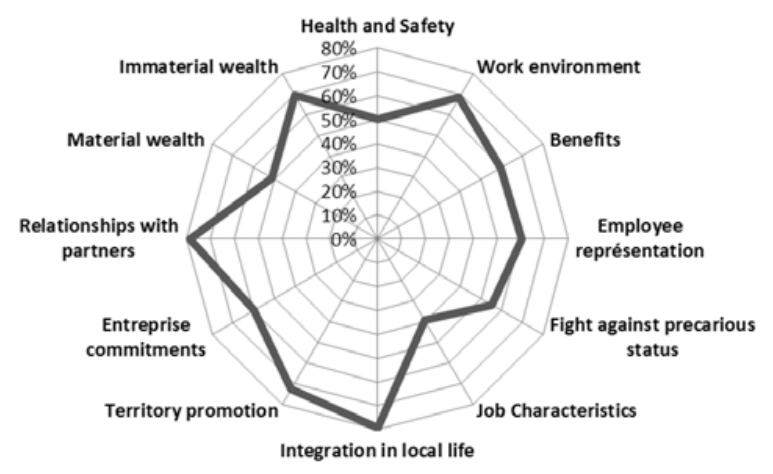

Figure 3. Performance of subcategories.

The first part of the results presents the results of the social performance of the Main chain operators by category and sub-categories of defined indicators, assessed with the evaluation grid and weighted by volume. The second part concerns the application of the regional multiplier method to characterize the total revenue generated by the whole supply chain activity in the territory and jobs created.

\subsection{Socio-economic performance of the supply chain}

In an overall assessment Beaujolais and Burgundy wines supply chain (private wineries, cooperatives wineries and traders) present a global performance of $\mathbf{5 9 \%}$. This study shows that for a supply chain under GI, the values attached to Territory Promotion and Integration in Local Life and Loyalty of Commercial Practices are high. There is indeed a cohesive construction of a Territory. However, the Workers Dignity Welfare and Wealth Creation should probably be reconsidered. At the moment we have no points of comparison with other supply chains that have used this method of analysis. The two categories having the greatest weight on the total score are those where the sector is less efficient. "Dignity and welfare of workers" (53\% of performance) and "Wealth Creation" (54\%). The other two categories have higher scores with more than $70 \%$ (Fig. 2).

To know the details of the performance and what practices affect it most significantly, the Fig. 3 shows the performance of the sub-categories.

\subsubsection{Category dignity and welfare of workers}

The subcategory "Work environment" has a score of $68 \%$. This score is mainly affected by the indicators of "Arrangements of working time" and "Provision of a convivial place" where companies are very efficient. The degree of integration of health and safety of workers is an indicator that lowers the performance of the supply chain. In general, the Single Document is not updated regularly and adapted; there is little particular consideration of these aspects, barely compliance with regulations. Difficult working conditions and compensatory measures decrease the performance of the sub-category. Despite this, the severity rate of accidents at work and occupational diseases are not very high, which increases the score positively.

Regarding the "benefits" offered to employees, pension and complementary health insurance are not routinely offered to all (often reserved for executives). However, the adopted collective agreements provide such complementary. Benefits in kind (wine) are often offered, benefits type "Works Council" (Discounts on vacation, shows, gift etc.) are less offered. A positive practice is quite common in the supply chain: the economic benefits to all employees (bonuses, 13th month, loans to employees, annuity payments). This raises the performance of this subcategory.

In the subcategory "representation of employees" the criterion of existence of a space for discussion on working conditions and company decisions is evaluated. Usually a collective space is not formalized, i.e. with representatives (staff delegates, syndicates, unique staff delegation, Works Council) and other (monthly team meetings, internal communications); collective or individual (individual interviews, satisfaction surveys etc.). The practice of only occasional meetings or daily discussions is recurrent.

Subcategory "fight against precarious status" (seasonal workers, temporary, trainees, and apprentices) was assessed through four indicators. Among these "respect for work and rest hours" is the most efficient. The Provision of facilities (accommodation, catering, transport, etc.), and the Perpetuation of seasonal workers (reemployed from one year to another or to other tasks) are the most fragile and least efficient criteria. Reducing costs explains the practices adopted, especially in cases where the grape harvest is mandatory manual (by GI specifications, pruning type, etc.) and wine prices are not high enough to offset these costs. Employment of foreigners for such tasks (considered as more difficult and without longterm contract of employment) is also one of the criteria considered in this subcategory; however it does not have a strong impact on its performance.

The "job characteristics" is the subcategory that most negatively impacts the performance of the "Dignity and welfare of workers". The comparison of wages of all employees (workers and executives) with those of the Sector Collective Agreements (SCA with 5,000 or more employees), managed by the Ministry of Labor, demonstrates that the wages of the workers and executives of the surveyed companies are generally lower than the convention. For the criterion of equality between men and women we have retained equality for the 'executives' and Board of Directors of companies. Equality between workers is not taken into account because there may be tasks that are specific to one gender, which would not be discriminating of equality. While 'executives' and 'Board of Directors (BOD)' have no gender specific tasks and are the highest positions in companies. For executives, there is a high level of gender equality in surveyed companies (compared to the wine sector and food industries), however in the 'BOD' the vast majority of men (50\% threshold) lowers the performance. The ratio of executives / total employees compared to the 
Sector Collective Agreement has a medium impact on the performance of the subcategory.

\subsubsection{Territory promotion and integration in local life}

The Territory Promotion and Integration in Local Life category shows that companies have good practices on their territory. In the subcategory "Integration in the local life" participation in local events is quite recurring, either financially or with human involvement. The villages organize many cultural events, sports and festivities and enterprises and their employees actively participate. Much of these events are also related to wine (a label of the territory) and therefore it involves local interests.

The criterion "complaints/comments" from neighbors about nuisances related to the activity (odors, noise, emissions, traffic, vibrations etc.) taken into account over the last 3 years show virtually no remarks and strong attention of companies not causing nuisance to local residents.

A third indicator should be considered in this subcategory, the "Professional Commitment" of companies on MDO's (Management and Defense Organizations), on Inter-professions and also on Trading Wine Federations. We were not able to evaluate it here; however, the lines for the creation of this indicator are included on the evaluation grid.

In the subcategory "Territory Promotion", the criterion "Identity of Territory" which measures participation in fairs, markets, saloons, receiving visitors, open doors etc. inside or outside of the supply chain area, has the best performance. As this is a supply chain under GI in addition to the reputation of French wine, companies regularly participate in promotional events. The landscapes of the zone are outstanding and nationally and internationally recognized. Burgundy (in the department of Côte D'Or more specifically) submitted its application to the UNESCO heritage. These territory features demonstrate the special effort to the preservation of buildings and landscape heritage. The supply chain is also performing on these criteria.

\subsubsection{Loyalty and integrity of commercial practices}

The environmental aspects are very popular in recent years, companies are more attentive to this criterion, and logically they are more engaged, making more effort in favor of the environment, and seeking to obtain certifications. Commitments in sanitary security and quality are also a major concern of companies. Mainly because of legislative constraints on food chains but also the requirements of importation companies, as the wine is a product with high exports. Standard Methods to sanitary/quality management (e.g. HACCP) are introduced or even certifications in sanitary safety and/or quality management (e.g. ISO 22000, ISO 9001, IFS / BRC, etc.). The commitments in the CSR field or the simple consideration of social aspects (formal or informal) are the weak points of the subcategory "Enterprise commitments". Very few companies have a formalized policy in social or societal terms. Generally only punctual actions are implemented in companies, which often simply follow the law. Again, the factor "company size" can influence the scores, because the actions of improvement in environmental, sanitary, quality and CSR are generally expensive and impacting more the costs of small companies.

The "relations with partners" is the best performing subcategory. Knowledge about competitors and its consideration to improve; the long-term partnerships with customers and suppliers (not only by volume and price aspects); and the involvement in joint projects (joint investment, joint purchasing, agricultural works company, sales group, etc.) increase the score in the subcategory. The organization of events with commercial partners is not regularly practiced by companies in the sector. The subcategory "subcontracts" is not analyzed here because subcontracting is not practiced by the majority of companies.

\subsubsection{Wealth creation}

The category "Wealth Creation" includes the subcategories "Immaterial Wealth" and "Material Wealth". About Immaterial wealth (staff training, relationship with research and training), the industry of wine is very organized, active and performing. Several research institutes and local and national councils implement participatory trials with companies in the chain. The enterprises also conduct internal tests with new products and processes. The "Innovation" aspect is not measured here as such because its assessment methodologies are fairly complex, but the sector is quite innovative and dynamic. A third indicator could be included in this subcategory to take into account the prestige of the supply chain, but that should be measured based on customer's analysis, which is not done in this study. The Beaujolais and Burgundy wines supply chain would probably have a good score, as many supply chains under GI.

However the composition of our approach gives greater importance to the criteria of material wealth, which in the short term, weight more in the sustainability of companies, especially on agricultural activity where instability of supply and market prices are determinant choices of commercial practices on all criteria over the years.

Among the indicators of material wealth, the economic efficacy of enterprises is quite low, despite the high rates of added value. The stocks weight of enterprises can affect the performance. The indicator "Wages/Added Value" is high, indicating that a large portion of the $\mathrm{AV}$ is paid in wages. This also explains the enterprise's low investments rate and the high burden of debt (debt ratio). This is an intense labor dependent supply chain and little mechanized in a country where wages are quite high. This implies a low margin for investment and the use of loans.

Subsidies as a percentage of Current Results before Taxes, shows that companies are quite dependent on subsidies.

Net income as a percentage of turnover, that is the income of the shareholders and managers/owners of farms, is a good performance indicator. However this result is fairly well distributed. Generally, farm managers and shareholders are the only ones rewarded. Only a few companies practice profit sharing for employees, still less the participation of employees in the capital. Despite this, companies have an average financial profitability 
Table 2. Total wealth and jobs created on the area (under the Regional Multipliers Method [15].

\begin{tabular}{|l|r|}
\hline Primary income & $1.852 .796 .831 €$ \\
\hline Secondary income & $864.322 .325 €$ \\
\hline Tertiary income & $29.137 .943 €$ \\
\hline Total revenue created on the Zone & $\mathbf{2 . 7 4 6 . 2 5 7 . 1 0 0} €$ \\
\hline Jobs created on the Zone (FTE) & $\mathbf{5 5 . 1 3 5}$ \\
\hline
\end{tabular}

(net income/capital) and also medium performance on the financial balance (liquidity).

Companies show a good cash flow. However, this indicator considers depreciation and net income which must compensate farm managers and shareholders. So companies have to use investments subsidies and loans in order to invest, which also explains the high rate of indebtedness.

\subsection{Income and jobs created}

Using the Regional Multipliers method, the total income generated by the Beaujolais and Burgundy industry on its territory is approximately $€ 2.7$ billion (see Table 2 ). Only the wealth that remains locally is taken into account i.e. the wealth which goes outside the territory is not counted. Overall each $€ 1$ of primary wealth created induces $€ 0.50$ of additional wealth (secondary + tertiary). Each hectoliter of wine produced on the industry creates approximately $€ 800$ of income that remain in the territory. According to the method, 55.135 FTE jobs are also created approximately. This number is certainly higher in terms of real jobs if considering jobs created by the wine tourism.

\section{Conclusion and perspectives}

The methodology proposed here shows a great ability to adapt to the local context, which captures the diversity of practices of local operators. It allows evaluating the performance, but also to go beyond the performance and capture its possible effects on the territory. It approximates to the "attributes method", which works in terms of performance measurement, but also the "effects method" where the potential effects of capacity (caught on companies practices) may allow the emergence of real effects of capacity (captured by comparisons between different operators and their performances). The aim of this method is not to predict the social impacts on populations caused by changes in the operation of a supply chain throughout its life cycle as the pathways method does.

The implementation of the "Regional Multipliers" is an asset to this method because it makes possible to estimate the total income and jobs created by the sector in a territorial assessment approach.

The methodology has also proved well suited to the analysis of a sector. We met operators that affect almost all life cycle of production of the supply chain over a year. Other operators that have not been met (transporters, service providers, consulting laboratories, vineyards) should be incorporated to improve the accuracy of results in the life cycle.

The first originality of this approach is to be based at the supply chain level and not the product, which brings significant methodological innovations, particularly in terms of system boundary, observation level, aggregation of the results from various operators at the step of characterization and representativeness. With this purpose different features are assessed: value creation, the welfare of workers, fair commercial relationships and involvement in the local territory and life. The second originality lies in the emphasis on the territorial impact: the study of geographical indications products is a particularly favorable framework for thinking about the regionalization of impacts. Beyond the inclusion of effects in a geographical territory, the analysis of the territorial impact will evaluate the contribution of the sector to build a lifestyle and a social link.

There are probably areas for improvement in the methodology that can be exploited and depth for future applications. But we believe that this methodology will help advance research on the Socio-Economic Life Cycle Analysis in a perspective of integration of environmental and socio-economic results for the analysis of sustainability in its entirety.

\section{References}

[1] M. Boström,. A missing pillar? Challenges in theorizing and practicing social sustainability: introduction to the special issue. Sustain. Sci. Pract. Policy 8, 3-14 (2012)

[2] A. Jørgensen, L.C. Dreyer, A. Wangel. Addressing the effect of social life cycle assessments. Int. J. Life Cycle Assess. 17, 828-839. doi:10.1007/s11367-0120408-9 (2012)

[3] C.B. Norris. Data for social LCA. Int. J. Life Cycle Assess. 19, 261-265. doi:10.1007/s11367-013-06447 (2014)

[4] L.C. Dreyer, M. Hauschild, J. Schierbeck. A Framework for Social Life Cycle Impact Assessment. Int. J. Life Cycle Assess. 11, 88-97. doi:10.1065/lca2005.08.223 (2006)

[5] G.A. Norris. Social Impacts in Product Life Cycles - Towards Life Cycle Attribute Assessment. Int. J. Life Cycle Assess. 11, 97-104. (2006). doi:10.1065/lca2006.04.017

[6] E. Andrews, P. Lesage, C. Benoît, J. Parent, G.A. Norris, J.-P. Revéret. Life Cycle Attribute Assessment: Case Study of Quebec Greenhouse Tomatoes. J. Ind. Ecol. 13, 565-578. (2009). doi:10. 1111/j.1530-9290.2009.00142.x

[7] S.A. Kruse, A. Flysjö, N. Kasperczyk, A.I. Scholz. Socioeconomic indicators as a complement to life cycle assessment - an application to salmon production systems. Int. J. Life Cycle Assess. 14, 8-18. doi:10.1007/s11367-008-0040-x (2009)

[8] D. Hunkeler. Societal LCA Methodology and Case Study (12 pp). Int. J. Life Cycle Assess. 11, 371-382. doi:10.1065/lca2006.08.261 (2006)

[9] B.P. Weidema. The Integration of Economic and Social Aspects in Life Cycle Impact Assessment. Int. J. Life Cycle Assess. 11, 89-96. (2006). doi:10.1065/lca2006.04.016

[10] J. Parent, C. Cucuzzella, J.-P. Revéret. Impact assessment in SLCA: sorting the sLCIA methods according to their outcomes. Int. J. Life Cycle Assess. 15, 164-171. (2010). doi:10.1007/s11367-009-0146-9 
[11] C. Gasnier, C. Macombe, S. Grimbuhler., Occupational health impact in life cycle organisations (2013)

[12] C. Macombe, P. Leskinen, P. Feschet, R. Antikainen. Social life cycle assessment of biodiesel production at three levels: a literature review and development needs. J. Clean. Prod. 52, 205-216. (2013) doi:10.1016/j.jclepro.2013.03.026

[13] M. Garrabé, A and Pedamay. MCM-ASCV des Capacités. Application à la filière tomate industrielle en France. Rapport 5 du projet ANR Alia FLONUDEP (2012)

[14] J.E. Fensterseifer and J.-L. Rastoin. Cluster resources and competitive advantage. A typology of otentially strategic wine cluster resources. International Journal of Wine Business Research. 25, 4, 267-284. doi: 10.1108/IJWBR-04-2011-0007 (2013)

[15] M. Garrabé. Valeur d'activité totale (V.A.T.) d'une opération de développement. Séminaire 3 - UM1IAMM (2014)

[16] V. Lempereur, S. Penavayre, G. Assogba, T. Majchrzak, C. Pernet, Méthodologie de description d'une filière. Application à la filière viti-vinicole du Beaujolais et de Bourgogne. 38ème Congrès Mondial de la Vigne et du Vin et 13ème Assemblée Générale de l'Organisation Internationale de la Vigne et du Vin (2015) 